\title{
Distribution and habitat use of the endangered Siberian flying squirrel Pteromys volans (Rodentia: Sciuridae)
}

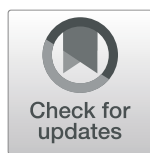

\author{
Sang Jin Lim', Ki Yoon Kim², Eui Kyeong Kim³ ${ }^{3}$ Chang Wook Han ${ }^{4}$ and Yung Chul Park ${ }^{2 *}$
}

\begin{abstract}
Background: Understanding the habitat characteristics of the endangered Siberian flying squirrel Pteromys volans is the first step in conserving and managing the forests it requires for nesting, gliding, and feeding. Therefore, in the present study, we characterized the habitats of $P$. volans using GIS analysis of 411 forest sites in South Korea where fecal droppings were found.

Results: Fecal signs of $P$. volans were found in various regions in South Korea, including the Baekdudaegan Mountains. GIS analysis with six environmental layers (vegetation type, wood-age class, diameter at breast height [DBH], crown density, elevation, and distance from stream) revealed that fecal signs of $P$. volans were more frequently found in broad-leaved deciduous forests (42\%) located 200-399 m above sea level (43.1\%) and 0-199 m from the nearest stream (53\%), with 5th class wood-age (35.3\%), middle size class DBH (51.1\%), and high crown density (71\%).

Conclusions: The present study provides information on the biotic and abiotic characteristics of $P$. volans habitats. In South Korea, the fecal droppings of $P$. volans were found predominantly old deciduous broadleaf forests. Further studies are needed to reveal whether the more frequent occurrence of $P$. volans dropping in broadleaf forests may be due to a particular preference of this species for the forests or to a simple reflection of the area of the broadleaf forests occupying a much larger area than other forest types in Korea.
\end{abstract}

Keywords: Habitat use, Pteromys volans, Siberian flying squirrel, GPS coordinates

\section{Background}

Siberian flying squirrels (Pteromys volans) (Sciuridae) are distributed from Finland and the Baltic Sea in the west to eastern Siberia and the Pacific Coast in the east, and their range includes the Korean Peninsula, Sakhalin Island in Russia, Northeast China, and Hokkaido in Japan (Cobet and Hill 1991; Nowak 1999; Won and Smith 1999; Hanski et al. 2000; Shar et al. 2016; Jo et al. 2018). Although P. volans is classified as a species of "Least Concern (LC)" in the IUCN Red List (Shar et al. 2016), it is classified as threatened at the national level

\footnotetext{
*Correspondence: parky@kangwon.ac.kr

${ }^{2}$ Division of Forest Science, College of Forest \& Environmental Sciences, Kangwon National University, Chuncheon 24341, Republic of Korea Full list of author information is available at the end of the article
}

in some countries. The species is nearly extinct in Latvia (Shar et al. 2016) and is classified as "Nearly Threatened" in Finland (Liukko et al. 2016) and "Vulnerable (VU)" in both Estonia and China (Red Data Book of Estonia 2008; Jiang et al. 2016).

In South Korea, $P$. volans is the only flying rodent that ranges from the northeastern boreal forests of the Peninsula to the Taebaek Mountains in the south (Won and Smith 1999; Jo et al. 2018). Due to population decline, the species was listed as a natural monument by the Cultural Heritage Administration in 1982 and an endangered species by the Ministry of Environment in South Korea in 1998 (Won and Smith 1999; Jo et al. 2018).

As is often the case among wildlife (Andrén 1994; Baillie et al. 2004), changes in forest structure and composition,

(c) The Author(s). 2021 Open Access This article is licensed under a Creative Commons Attribution 4.0 International License, which permits use, sharing, adaptation, distribution and reproduction in any medium or format, as long as you give appropriate credit to the original author(s) and the source, provide a link to the Creative Commons licence, and indicate if changes were made. The images or other third party material in this article are included in the article's Creative Commons licence, unless indicated otherwise in a credit line to the material. If material is not included in the article's Creative Commons licence and your intended use is not permitted by statutory regulation or exceeds the permitted use, you will need to obtain permission directly from the copyright holder. To view a copy of this licence, visit http://creativecommons.org/licenses/by/4.0/. 
as well as habitat loss (e.g., logging), may be directly linked to the population decline of $P$. volans (Hokkanen et al. 1982; Lampila et al. 2009). Therefore, understanding their habitat characteristics is the first step in conserving and managing the forests that this endangered species requires for nest cavities, winter food, and gliding.

Although the habitat characteristics of $P$. volans have been relatively well studied in other countries, particularly Finland (Hanski 1998; Hanski et al. 2000; Timm and Kiristaja 2002; Airapetyants and Fokin 2003; Hurme et al. 2007; Selonen and Mäkeläinen 2017), they have not been adequately studied in South Korea, and the areas that have been studied are restricted to local habitat ranges (Cho et al. 2013; Kim et al. 2020). In the present study, we provide information on habitat characteristics of $P$. volans in South Korea using GIS analysis of locations in various forest regions where fecal droppings were found.

\section{Materials and methods}

The GPS coordinates of 411 fecal signs of P. volans were extracted from wildlife signs collected through the National Park Natural Resources Survey and National Natural Environment Survey, which were conducted in South Korea from July 2011 to November 2017. Surveys of wildlife were conducted according to the Guidelines for the 3rd and 4rd National Natural Environment Surveys (Jeong et al. 2006; Hyeon et al. 2012). The droppings of $P$. volans were identified according to the morphological characteristics described in the previous papers (Woo et al. 2013; Han et al. 2018).

Biotic (vegetation, wood-age class, diameter at breast height $[\mathrm{DBH}]$, and crown density) and abiotic (elevation and distance from stream) components of the areas where $P$. volans droppings occurred were selected for GIS-based habitat analysis (Lim et al. 2015a, 2015b). Information on vegetation, wood-age class, DBH, and crown density was obtained from the 5th Digital Forest Cover Type map (Forest Service, South Korea). Elevation information was collected from a digital elevation model (Aster GDEM, NASA), which was constructed by extracting the contour layer from a digital topographic map of 1:5000 accumulation. Information on the distance from the nearest stream was obtained from the Water Resources Management Information System of the Ministry of Environment, South Korea. Spatial analysis of the habitat components was conducted using ArcGIS 10.1 (ESRI Inc., Redlands, CA, USA), with a spatial resolution of $30 \mathrm{~m}$ for all layers.

\section{Results and discussion}

Many fecal signs of $P$. volans were found in the Baekdudaegan and its surrounding region, an elongated mountain ridge that runs almost the entire length of the
Korean Peninsula from Mt. Baekdusan in the north to Jirisan National Park in the south (Fig. 1). Of the 411 fecal sings, 38 signs were found within the Baekdudaegan Protected Area. According to GIS analysis of the fecal sign locations $(n=411)$ with the environmental GIS layers (Fig. 2), the fecal signs of $P$. volans were more often found in broadleaf deciduous forests (42\%) (Fig. 3A), with 5 th class wood-age (35.3\%) (Fig. 3B), middle size class DBH (51.1\%) (Fig. 3C), and high crown density (71\%) (Fig. 3D). The signs $(n=411)$ were primarily found at 200-399 m above sea level (43.1\%; mean $483 \pm 296$ $\mathrm{m}$; range 36-1496 m) (Fig. 3E) and 0-199 $\mathrm{m}$ from the nearest stream (53\%; mean $236 \pm 205 \mathrm{~m}$; range 0-1060 m) (Fig. 3F).

A recent habitat study conducted in South Korea (see Table 5 in Kim et al. 2020) indicated that P. volans preferred deciduous forests (54\%) with $\mathrm{DBH}$ of $18-30$ $\mathrm{cm}$ and high crown density rather than coniferous $(30 \%)$ or mixed forests (16\%), despite the fact that available habitats consisted of primarily coniferous forests (48\%). These results are similar to those in the present study (Fig. 3), except that our results indicated a preference for the 5th wood age class, whereas the 4th age class was preferred in the previous study. Another earlier study also revealed that $63.3 \%$ of $30 \mathrm{P}$. volans signs, including 15 nests and 15 droppings, were found in deciduous trees in mixed forests (Cho et al. 2013).

According to our study and the other studies previously conducted in South Korea, the Korean P. volans appears to prefer deciduous forests than coniferous forests. However, it cannot also be ruled out that more findings of $P$. volans droppings in broadleaf deciduous forests may be related to the type of the vegetation that dominates in South Korea rather than to a greater preference of $P$. volans for broadleaf forests. The most common forest type in South Korea is deciduous broadleaf forests in warm-temperate zone, whereas coniferous or mixed forests are restricted to only small areas of high mountains (Figs. 2A, E). This may explain why the fecal droppings are more common in deciduous broadleaf forests than coniferous forests in South Korea.

There are previous studies that can correlate the distribution of $P$. volans with dominant vegetation of habitats (Hanski 1998; Reunanen et al. 2002; Timm and Kiristaja 2002; Airapetyants and Fokin 2003; Santangeli et al. 2013). Forests in the boreal regions of Finland, Russia, and Estonia are dominated over most of their range by coniferous trees, especially species of spruce, pine, larch, and fir, with some broadleaf species of aspen, birch, poplar, alder, and willow (Freedman 1999). In these boreal countries, $P$. volans inhabits mature conifer-dominated forests with a mixture of deciduous trees, such as birch, alder, and aspen (Hanski 1998; Reunanen et al. 2002; Timm and Kiristaja 2002; Airapetyants and Fokin 2003; 


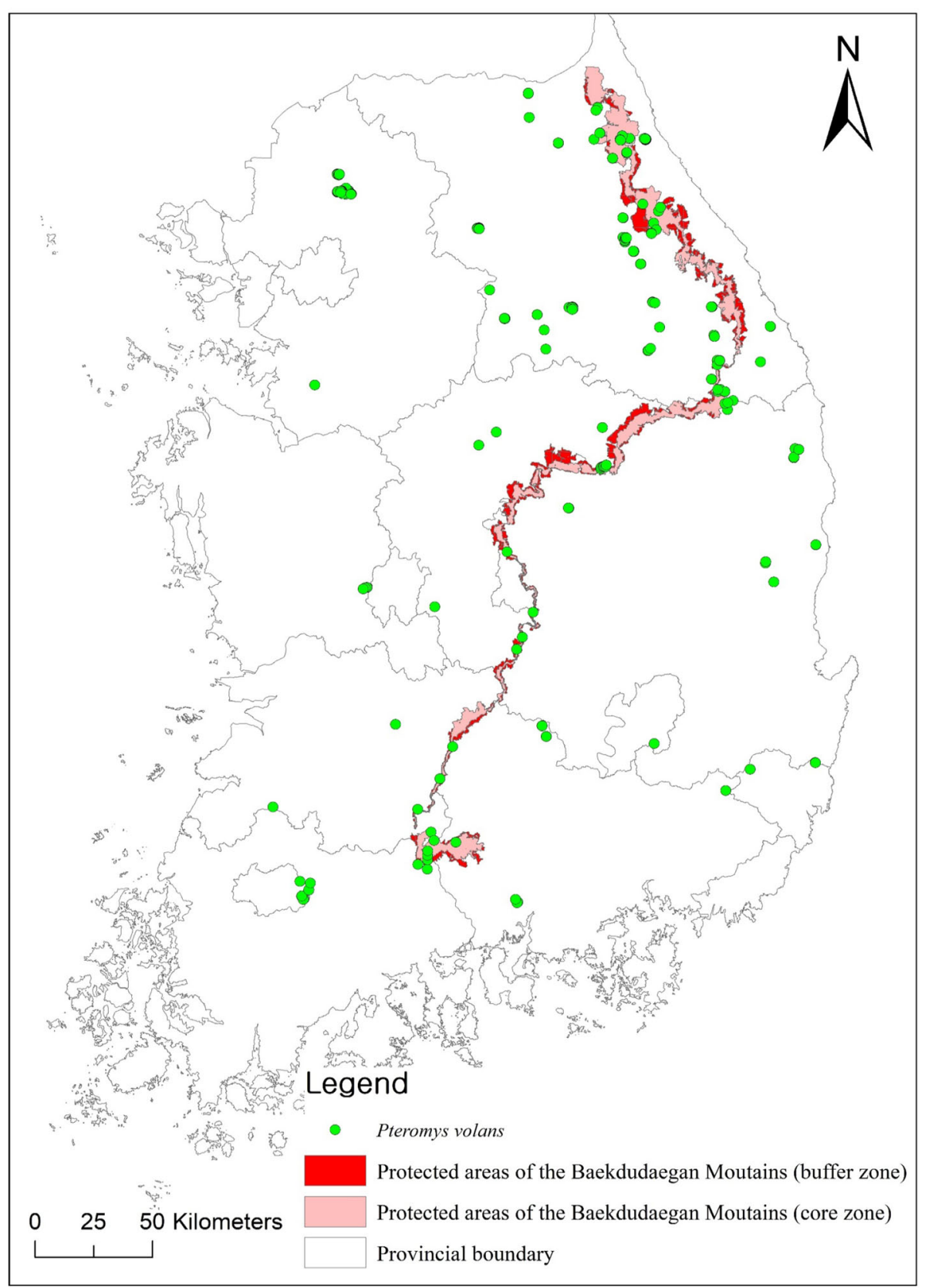

Fig. 1 Distribution of fecal sites $(n=411)$ of Siberian flying squirrel Pteromys volans in South Korea

Santangeli et al. 2013). Pteromys volans feeds mainly on the leaves of deciduous trees in summer (Mäkelä 1996), while catkins of birch and alder, as well as buds of both coniferous and deciduous trees, are used as food in winter and early spring (Mäkelä 1996; Hanski 1998; Selonen and Mäkeläinen 2017). In those boreal countries, therefore, the frequent use of coniferous forests as the species' primary habitat may have more to do with the broader dominance of coniferous forests in boreal regions rather than because of a greater preference for conifers.
In this study, the droppings of the Korean $P$. volans were found more frequently in broadleaf forests. However, the data used for GIS analysis of forest types was restricted to the sites where $P$. volans droppings were found within the surveyed areas, whereas those where the droppings were not found were not included. Therefore, through this study, it cannot be confirmed whether the more frequent finding of their droppings in broadleaf forests is due to the greater preference of $P$. volans for broadleaf forests or to the broader occupation of broadleaf forests in South Korea. 


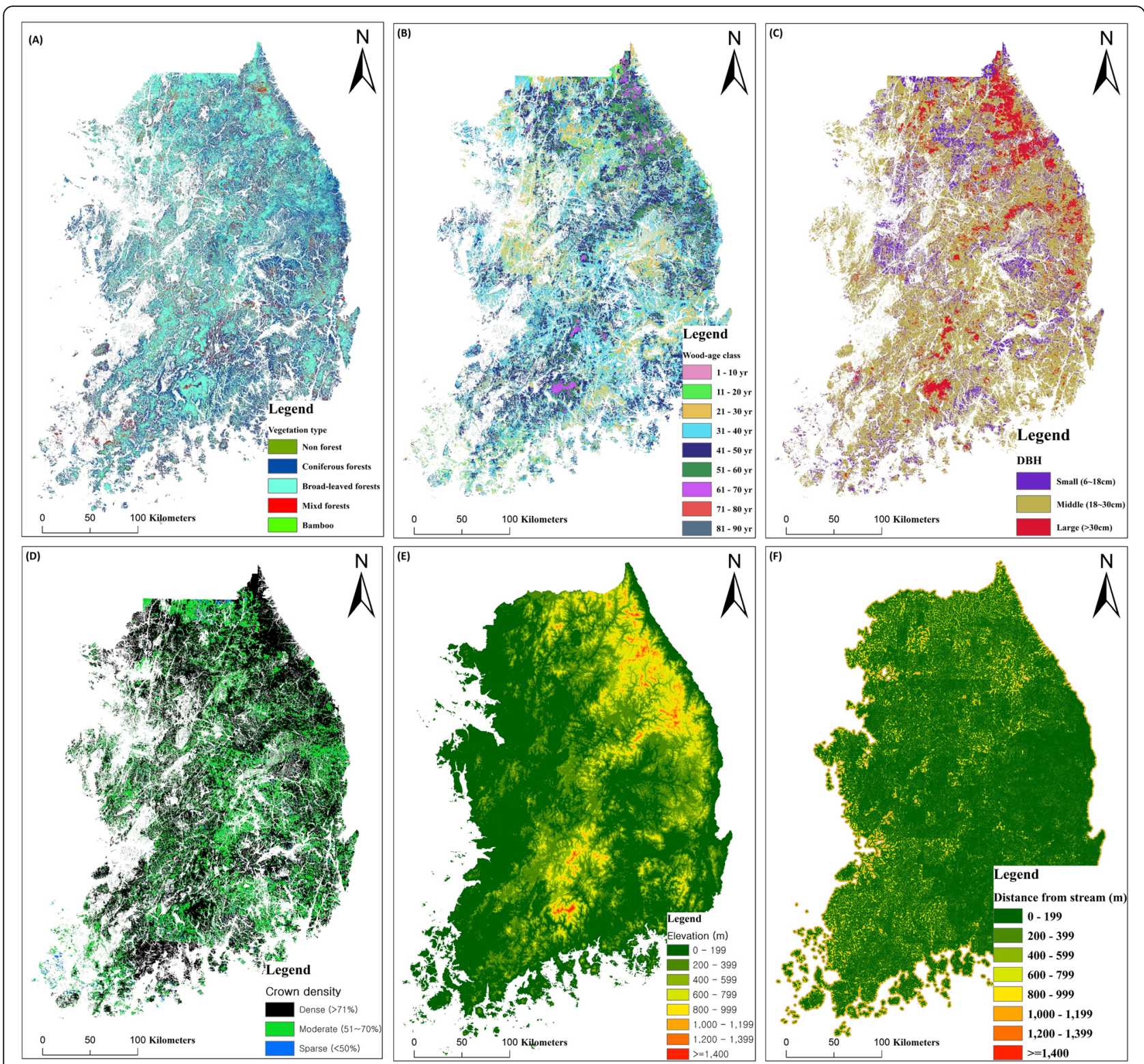

Fig. 2 GIS layers of vegetation (A), wood-age class (B), diameter at breast height (DBH) (C), crown density (D), elevation (E), and distance from stream (F)

To confirm the forest types (deciduous, coniferous, or mixed trees) preferred by $P$. volans, in future research, the overall forest types within the entire survey area should be compared with the forest type of the area where $P$. volans droppings were found within the survey area. In addition, it is necessary to investigate the forest types of not only the areas where the droppings were found within the survey area, but also the areas where they were not found.

\section{Conclusions}

The present study provides information on biotic (vegetation type, wood-age class, DBH, and crown density) and abiotic (elevation and distance from stream) habitats of the endangered $P$. volans in South Korea. The fecal signs of $P$. volans were more often found in old deciduous broadleaf forests in South Korea, in contrast to other countries such as Finland, Russia, and Estonia, in which they were mainly found in conifer-dominated forests. The results of our study are good agreement with those of the previous studies conducted in South Korea on the forest types preferred by P. volans (Cho et al. 2013; Kim et al. 2020). The more frequent occurrence of $P$. volans droppings in broadleaf forests may be because this species prefers the forests than other forest types. Another possibility may be because broadleaf forests are spread 


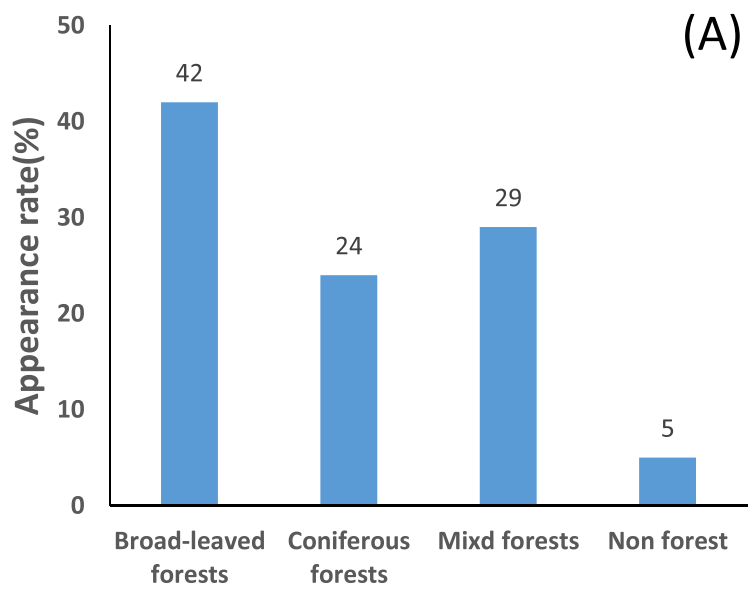

Vegetation type

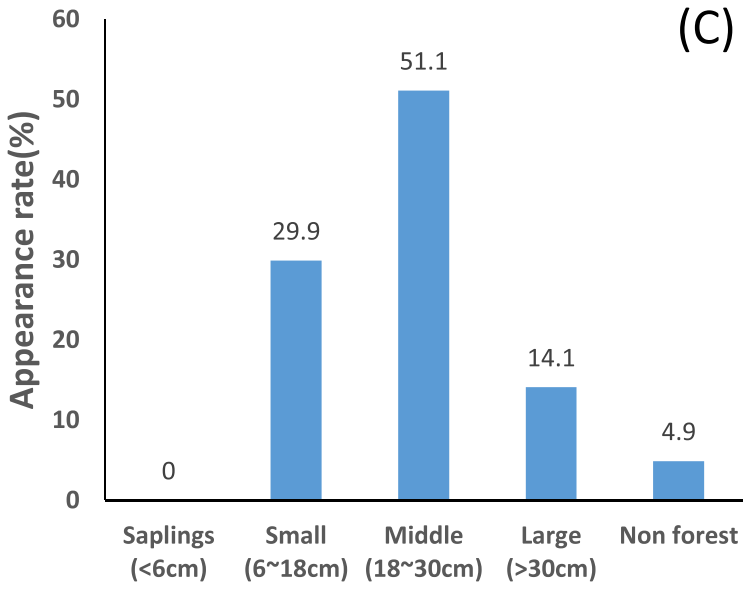

DBH

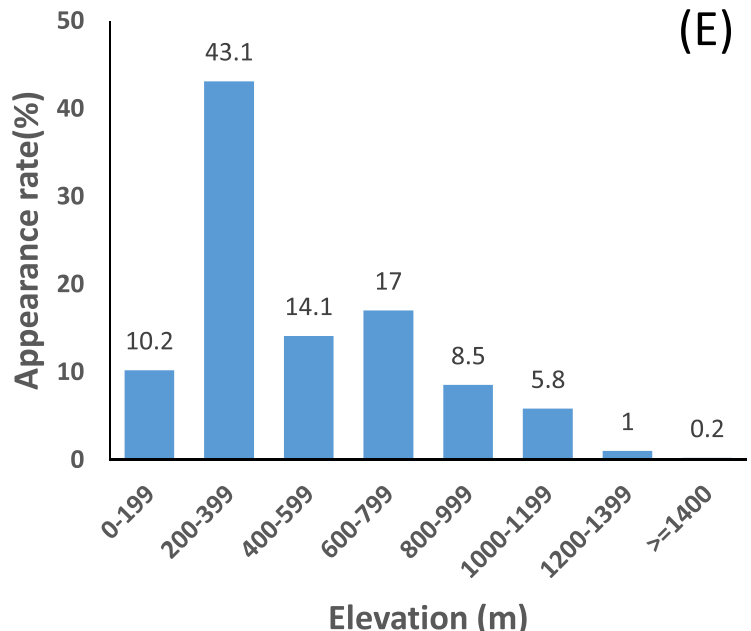

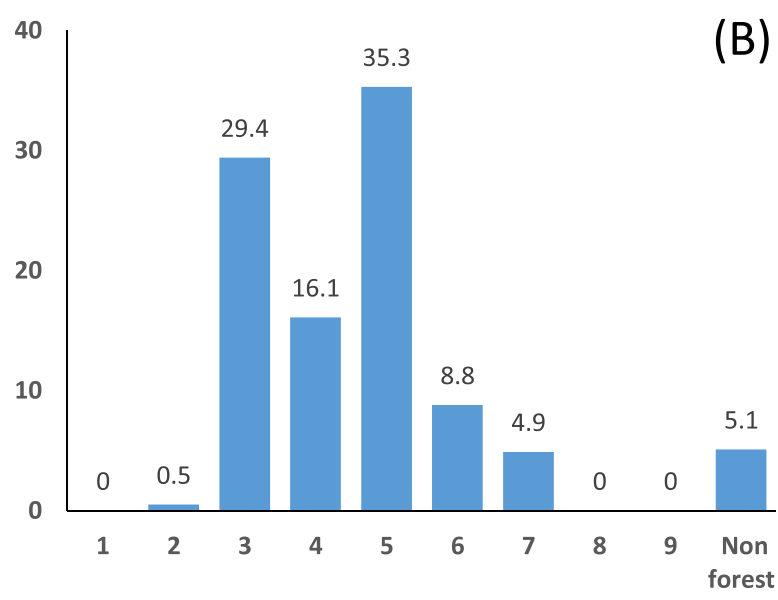

Wood-age class(10yr)

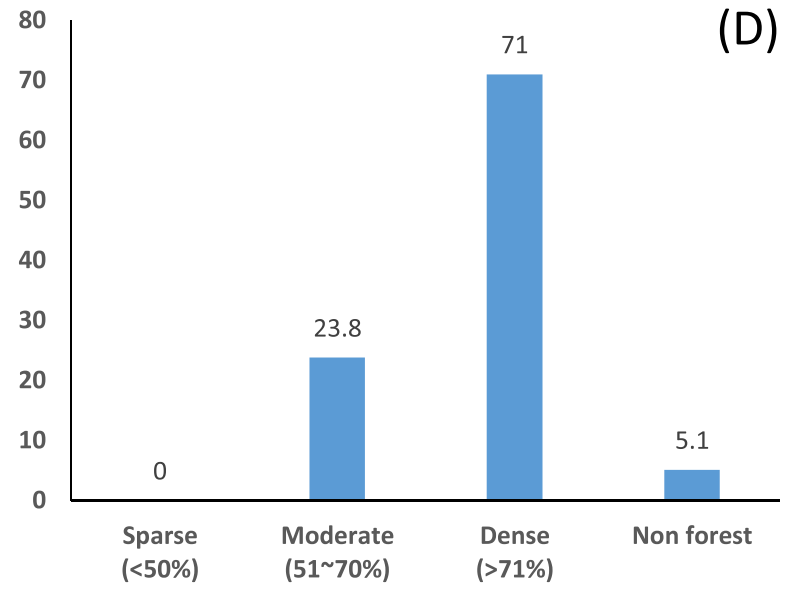

Crown density

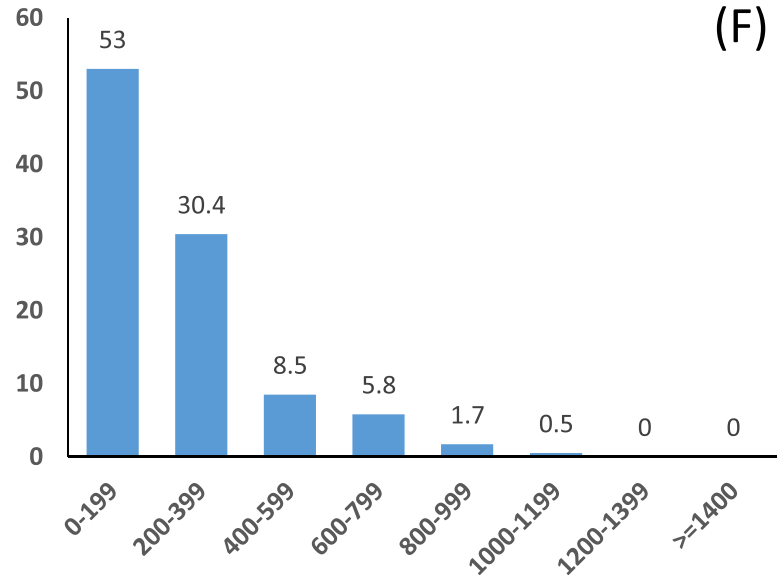

Distance from stream $(\mathrm{m})$

Fig. 3 Appearance percentage of Pteromys volans signs ( $n=411)$ by vegetation type $(\mathbf{A})$, wood-age class $(\mathbf{B})$, diameter at breast height (DBH) (C), crown density (D), elevation (E), and distance from stream (F) 
over a much larger area than other forest types in South Korea, rather than a particular preference of this species for broadleaf forests. In further studies, the forest types in the dropping-discovered and non-discovered sites in the survey area should be compared to identify the forest type favored by $P$. volans. Our results can benefit wildlife ecologists working on the conservation and habitat management of the Siberian flying squirrel and related species.

\section{Abbreviations}

DBH: Diameter at breast height; DEM: Digital elevation mode

\section{Acknowledgements}

We are grateful to anonymous reviewers for valuable comments on a draft of this paper.

\section{Authors' contributions}

LSJ: Data collection, writing - original draft, and GIS analysis; KKY: Data collection; KEK: Data collection; HCW: Data collection; PYC: Data collection, research grant acquisition, research design, and writing - review and editing. The author(s) read and approved the final manuscript.

\section{Funding}

This study was supported by the Cultural Heritage Administration of the Republic of Korea (2015-2016) and 2017 Research Grant from Kangwon National University (No. 520170345).

\section{Availability of data and materials}

The datasets collected during and/or analyzed during the current study are available from the corresponding author on reasonable request.

\section{Declarations}

Ethics approval and consent to participate

Not applicable.

\section{Consent for publication}

Not applicable.

\section{Competing interests}

The authors declare that they have no competing financial interests or personal relationships that influenced or could be perceived to have influenced the work reported in this article.

\section{Author details}

${ }^{1}$ Institute of Forest Science, Kangwon National University, Chuncheon 24341, Republic of Korea. ${ }^{2}$ Division of Forest Science, College of Forest \& Environmental Sciences, Kangwon National University, Chuncheon 24341 , Republic of Korea. ${ }^{3}$ Division of Ecological Survey, Research Institute of Korea National Park, Wonju 26441, Republic of Korea. ${ }^{4}$ Environmental Research Institute, Kangwon National University, Chuncheon 24341, Republic of Korea.

\section{Received: 7 March 2021 Accepted: 11 August 2021}

\section{Published online: 03 October 2021}

\section{References}

Airapetyants AE, Fokin IM. Biology of European flying squirrel Pteromys volans L. (Rodentia: Pteromyidae) in the north-west of Russia. Russ J Theriol. 2003;2: $105-13$.

Andrén $\mathrm{H}$. Effects of habitat fragmentation on birds and mammals in landscapes with different proportions of suitable habitat: a review. Oikos. 1994;71(3):355. https://doi.org/10.2307/3545823.

Baillie JEM, Hilton-Taylor C, Stuart SN, editors. 2004 IUCN red list of threatened species: a global species assessment. Gland and Cambridge: IUCN; 2004.

Cho HJ, Kim DH, Kang TH, Kim IK, Lee JW. Basic research on the habitat characteristics of endangered species Pteromys volans. Kor J Environ Ecol. 2013;27(5):544-9. https://doi.org/10.13047/KJEE.2013.27.5.544.
Cobet GB, Hill JE. A world list of mammalian species. 3rd ed: Oxford University Press; 1991.

Freedman B. Boreal forest (taiga). In: Environmental Geology. Encyclopedia of Earth Science. Dordrecht: Springer; 1999. https://doi.org/10.1007/1-4020-44 94-1_43.

Han CH, Lim SJ, Park HB, Park YC. Seasonal characteristics of fecal sites of the Siberian flying squirrel Pteromys volans. J For Environ Sci. 2018;34:184-7.

Hanski IK. Home ranges and habitat use in the declining flying squirrel Pteromys volans in managed forests. Wildl Biol. 1998;4(1):33-46. https://doi.org/10.2 981/wlb.1998.013.

Hanski IK, Stevens PC, Ihalempiä P, Selonen V. Home-range size, movements, and nest-site use in the Siberian flying squirrel, Pteromys volans. J Mammal. 2000; 81(3):798-809. https://doi.org/10.1644/1545-1542(2000)081<0798:HRSM $\mathrm{AN}>2.3 . \mathrm{CO} ; 2$

Hokkanen $\mathrm{H}$, Törmälä T, Vuorinen $\mathrm{H}$. Decline of the flying squirrel Pteromys volans L. populations in Finland. Biol Conserv. 1982;23(4):273-84. https://doi.org/10.1 016/0006-3207(82)90083-0.

Hurme E, Reunanen P, Mönkkönen M, Nikula A, Nivala V, Oksanen J. Local habitat patch pattern of the Siberian flying squirrel in a managed boreal forest. Ecography. 2007;30(2):277-87. https://doi.org/10.1111/j.0906-7590.2 007.04744.x.

Hyeon JO, Na HL, Park G, Kim JW, Lim HT, et al. Guideline for The 4rd National Natural and Environment Survey: Korea Ministry of Environment and Institute of Environmental Research; 2012.

Jeong HR, Rho PH, Song JY, Kim JW, Kim MS, et al. Guideline for The 3rd National Natural and Environment Survey: Korea Environment Institute; 2006.

Jiang Z, Wang Y, Zhang E, Zhang Y, et al. Red list of China's vertebrates. Biodivers Sci. 2016; https://www.biodiversity-science.net/EN/10.17520/biods.2016076.

Jo YS, Baccus JT, Koprowski JL. Mammals of Korea: a review of their taxonomy, distribution and conservation status. Zootaxa. 2018;4522(1):1-216. https://doi. org/10.11646/zootaxa.4522.1.1.

Kim JU, Kim JS, Jeon JH, Lee WS. Home range estimates and habitat use of Siberian flying squirrels in South Korea. Animals. 2020;10(8). https://doi.org/1 0.3390/ani10081378.

Lampila S, Kvist L, Wistbacka R, Orell M. Genetic diversity and population differentiation in the endangered Siberian flying squirrel (Pteromys volans) in a fragmented landscape. Eur J Wildl Res. 2009;55(4):397-406. https://doi.org/1 0.1007/s10344-009-0259-2

Lim SJ, Kim JY, Park YC. Analysis of habitat characteristics of leopard cat (Prionailurus bengalensis) in Odaesan National Park. J Agri Life Sci. 2015a;49(3): 99-111. https://doi.org/10.14397/jals.2015.49.3.99.

Lim SJ, Min JH, Park YC. Analysis of habitat characteristics of the yellow-throated marten Martes flavigula (Carnivora: Mustelidae) using geographic information system (GIS). J For Env Sci. 2015b;31(4):261-6. https://doi.org/10.7747/JFES.2 015.31.4.261.

Liukko UM, Henttonen H, Hanski IK, Kauhala K, Kojola I, Kyheröinen EM, et al. The 2015 Red List of Finnish Mammal Species. Helsinki: Finnish Environment Institute; 2016. http://hdl.handle.net/10138/159434

Mäkelä A. Liito-oravan (Pteromys volans L.) lisään tymisbiologiasta. - The World Wildlife Fund Report no 8. Helsinki; 1996. p. 63-6. (In Finnish).

Nowak RM. Walker's mammals of the world. 6th ed. Baltimore: Johns Hopkins University Press; 1999.

Red Data Book of Estonia. Commission for Nature Conservation of the Estonian Academy of Sciences. 2008. https://vana.elurikkus.ut.ee/prmt.php?lang=eng (accessed date: 2 March 2021).

Reunanen P, Mönkkönen M, Nikula A. Habitat requirements of the Siberian flying squirrel in northern Finland: comparing field survey and remote sensing data. Ann Zool Fenn. 2002; https://www.jstor.org/stable/23735798.

Santangeli A, Hanski IK, Mäkelä H. Integrating multi-source forest inventory and animal survey data to assess nationwide distribution and habitat correlates of the Siberian flying squirrel. Biol Conserv. 2013;157:31-8. https://doi.org/10.101 6/j.biocon.2012.06.027.

Selonen V, Mäkeläinen SLM. Ecology and protection of a flagship species, the Siberian flying squirrel. Hystrix. 2017. https://doi.org/10.4404/hystrix-28.2-12328.

Shar S, Lkhagvasuren D, Henttonen H, Maran T, Hanski I. Pteromys volans (errata version published in 2017): The IUCN Red List of Threatened Species 2016; 2016. https://doi.org/10.2305/IUCN.UK.2016-3.RLTS.T18702A22270935.en. (Downloaded on 27 February 2021)

Timm U, Kiristaja P. The Siberian flying squirrel (Pteromys volans L.) in Estonia. Acta Zool Litu. 2002;12(4):433-6. https://doi.org/10.1080/13921 657.2002.10512535 
Won C, Smith KG. History and current status of mammals of the Korean Peninsula. Mammal Rev. 1999;29(1):3-36. https://doi.org/10.1046/j.1365-2907.1 999.00034.x.

Woo DG, Choi TY, Lee SG, Ha JG. A study on dropping behavior and survey improvement methods for Siberian flying squirrel (Pteromys volans). J Env Impact Assess. 2013;22(6):569-79.

\section{Publisher's Note}

Springer Nature remains neutral with regard to jurisdictional claims in published maps and institutional affiliations.

\section{Ready to submit your research? Choose BMC and benefit from:}

- fast, convenient online submission

- thorough peer review by experienced researchers in your field

- rapid publication on acceptance

- support for research data, including large and complex data types

- gold Open Access which fosters wider collaboration and increased citations

- maximum visibility for your research: over $100 \mathrm{M}$ website views per year

At $\mathrm{BMC}$, research is always in progress. 